\title{
Micro-Entrepreneurship: Tendency towards Precarious Work? Empirical Findings for Austria
}

\author{
By Dieter Bogenhold* \\ Andrea Klinglmair ${ }^{\dagger}$
}

The complex interaction of technological development, globalisation and socio-demographic change has accelerated a structural change in the economy, resulting in a changing working environment and new forms of employment. In the field of self-employment, an emerging trend can be observed towards one-person enterprises, which already represent more than 50 percent of all Austrian companies. The primary aim of this paper is to analyse the rationalities of these microenterprises based on an empirical online survey of one-person enterprises in Carinthia; the focus of the analysis is the motive for being self-employed. We found evidence that one-person entrepreneurs are mainly driven by motives like selfrealization or working without hierarchies. However, there are also one-person entrepreneurs who have been crowded out from the (dependent) labour market and are therefore driven by economic reasons (e.g. self-employment as an alternative to unemployment). This economically driven group of one-person enterprises is comparatively dissatisfied with their professional situation, is less optimistic regarding their entrepreneurial future, and generates lower incomes.

\section{Introduction}

Entrepreneurship has become a central issue when discussing ways to promote job creation and growth. Especially in the context of IT technologies and ideas on innovative regional clusters, entrepreneurship has evolved to be a pivot for a sustainable economic and social future (Audretsch, 2007; Bonnet et al., 2010; 2012). However, critical discourse shows that entrepreneurship as a terminus technicus in scientific discussion is not always precisely defined. In particular, the socioeconomic heterogeneity of the human actors and their different occupational and biographical careers and orientations are not sufficiently acknowledged. Taking the labour market category of selfemployment as a proxy for entrepreneurship, which is often practised - and discussed critically -, one realizes that the majority of entrepreneurs is

${ }^{*}$ Professor, Alpen-Adria University Klagenfurt, Austria.

${ }^{\dagger}$ Institute of Advanced Studies, Austria. 
associated with the category of micro-firms, which are mainly one-(wo)man firms.

The complex processes of interplay between technological change, globalisation and the labour market leading to a shift towards a service sector economy are mirrored by the emergence of new patterns of employment and the related institutional context. Viewing the issue of self-employment, a growing trend towards part-time self-employment and one-(wo)man firms can be found. These newly emerging firms are increasingly regarded as an alternative to wage- or salary-dependent working. While Schumpeter (1912) portrayed the actor of entrepreneurship as "captain of industry", most of these small business owners do not fit this metaphor: They do not operate with different hierarchy levels and they work in their companies without any employees. Occasionally, their work situations show a hybrid status between dependent employed working and the idealised idea of autonomy associated with the semantic of entrepreneurship (Folta et al., 2010).

The findings of our study try to shed light on the issue of the real world of smallest businessmen and to gain new information to fill a knowledge gap. Slightly more than 70 percent of all self-employed people in Europe (EU-28) fall into the category of independent businessmen who work without further employees (Eurostat-Database, 2014). These one-(wo)man firms don't share the conventional portrait of economic and social features which is conventionally reported as stereotype on big companies. What is the rationality of actors being involved in these micro-firms, what are their economic and social intentions, which occupational biographies can be reported, and how can the phenomenon of micro-self-employment be interpreted most adequately? The paper is based upon findings of a representative survey in one federal country in Austria (Carinthia) solving as a pilot-study for further investigation.

The research question focuses on these forms of micro-entrepreneurship asking for diverse aspects of economic and social performance like income, motives for self-employment, well-being, job satisfaction or prospects for the future. The paper will identify one-person enterprises that are self-employed due to missing chances in the labour market ("precarious" forms). Then, this group of companies will be compared with their non-precarious counterparts with respect to various factors like job satisfaction, business performance or future prospects. The rest of this paper is structured as follows. In the following section the theoretical background will be explored while the next part refers to the role of one-person enterprises in Austria based on data from official statistics. The next section contains the design of the empirical study in Austria and the major empirical findings. The concluding section tries to put the findings in a nutshell.

\section{Theoretical Background}

Academic discussion has no doubt that new self-employment has a necessary impact for the vitality of our modern economies. It is argued that 
increasing self-employment contributes to wealth, increasing jobs and to a better integration of society (OECD and The European Commission, 2013; Amoros et al., 2014). Although this view is convincing for many reasons, too less is stressed upon the fact of the considerable heterogeneity of selfemployment. "This heterogeneity and modest-majority dominance is a challenge for researchers" (Davidsson, 2014, 6). Most of them show very limited ambitions, resources and novelty. Very few will ever embark on a trajectory of growth (Davidsson et al., 2010). Therefore, we must acknowledge a broad range of social and economic situations within the scope of entrepreneurship where the majority belongs to the category of smallest firms. In principle, two competing interpretations of the phenomenon of one-(wo)men enterprises are on the agenda: One is a negative-critical perspective and the other is a positive-optimistic one. The first interpretation views the phenomenon in combination with new tendencies of instabilities on the labour market (Kalleberg, 2009; 2011), when many labour market participants are pushed into micro self-employment due to a lack of (paid) jobs and tendencies of flexibilization in order to find a niche in the employment system at all (Acemoglu, 2002; Tilly, 1996). On the other hand, it is argued that an economy is permanently dependent upon new business entries, which - by their nature start as small and smallest. These new entries represent fertile ground for firms, which potentially grow and subsequently provide impulses for the labour market and technological development. In this last view, micro-firms are regarded as a bridge to positive spillover effects. However, a third intermediating - perspective refers to the point that several one-person firms engage consciously within the smallest size sector and do not have ambitions for growth, for various reasons. These business owners are satisfied, if they can realize a sufficient income through free-lance work or micro-entrepreneurship, and they do not want to replace further growth with less leisure time or other different packages of work duties.

According to Shane and Venkataraman (2000) three sets of research questions about entrepreneurship are central:

(1) Why, when, and how opportunities come into existence?

(2) Why, when, and how some people and not others discover and exploit these opportunities?

(3) Why, when, and how different modes of action are used to exploit entrepreneurial opportunities?

Additionally, to this tableau of research domains one may raise the question of where the entrepreneurs come from, how they sustain themselves, what their occupational and social biographies are within the division of work. Related to this question, one may continue with specific social issues of relevance: Which divergent social networks can people instrumentalize to operate their strategies and to maximize their social positions (Davidsson and Honig, 2003; Burt et al., 2013; Bögenhold 2013)? Reasoning about the future of entrepreneurship (Wiklund et al., 2011) shall include these sociological 
questions (Bögenhold et al., 2014a). Nevertheless, we are increasingly in a world society with a puzzle of labour market patterns and biographical careers in which the clinical dichotomy between wage- or labour-dependent work on the one side and self-employed activities on the other side is muddied since hybrid forms of combinations arise, where people have more than one job at one time, or along the biographical axis of individual careers so that we observe patterns of multiplicity and parallelisms in which entrepreneurship seems to be a complex process, often a long duration (Davidsson, 2014).

If we employ the labour market category of self-employment as a proxy for entrepreneurship, which may occasionally be questioned but which most closely resembles actual practice, it becomes evident that in many countries the majority of entrepreneurs belongs to the category of micro firms, which effectively exist as one-(wo)man companies, with many of their number not even being registered in the yellow pages or having their own premises or sign above the door (Bögenhold et al., 2014b). Generally, the complex interaction of technological development, globalization, decentralization and sociodemographic change accelerated a structural change in the economy resulting in a changing working environment and new forms of employment. In the field of self-employment, an emerging trend towards part-time self-employment and one-person enterprises can be observed. These new born forms of entrepreneurship are increasingly regarded as an important alternative to dependent employment (Korunka et al., 2011).

In some way, their current status and their biographies display a somewhat hybrid nature, positioned between wage or salary dependency and the freedom of entrepreneurs in their stereo-type (Folta et al., 2010). "Die-hard entrepreneurs" (Burke et al., 2005) are those actors, who are portrayed in public discourse and also in economics as those agents, who are dynamic, willing to expand and to engage in risk taking. Conversely, those selfemployed actors who do not meet with this image, but who are the majority of people in terms of self-employment numbers, seem to be rather neglected (Bögenhold et al., 2001; Bögenhold and Fachinger 2007). Since most of the theories in economics are based upon the observation of a dozen of giant firms (Stigler, 1949), one has to turn attention to the real world of the economy with the majority of firm owners who are part-time workers and part-time entrepreneurs (Leicht 2000).

\section{The Role of One-person Enterprises in Austria}

In Austria as well as the European Union as a whole (EU-28) an increase of self-employment has been observed for several years. In particular, the number of self-employed people in Austria rose from 439,100 in 2004 to 476,900 in 2013, which represents an increase of 8.6 percent. ${ }^{1}$ Especially female self-employment went up with significant ratios of increase, when their numbers evolved by 14.1 percent; the increase of male self-employment was

\footnotetext{
${ }^{1}$ In the same period, the number of dependent employees increased by 10.8 percent.
} 
just at 5.9 percent (Statistik Austria, 2014). In the EU-28, total selfemployment increased in the same time period by merely 1.3 percent. As in Austria, female self-employment has risen disproportionately by 8.1 percent since 2004, while the number of male self-employed went down by 1.6 percent (Eurostat-Database, 2014).

The category of self-employment can be split into two subcategories. On the one side, self-employed people hire additional labour in their companies, and on the other side there are those who just work on their own without any further employees in their companies. According to Eurostat-Database (2014), the category of solo-entrepreneurs with micro-enterprises without further employees in their firms is about 59.9 percent of all self-employed people in Austria. In the EU-28, by contrast, the share of solo-self-employed to total selfemployment is even higher and amounts to 71.3 percent. Furthermore, the Austrian statistics indicate the high relevance of one-(wo)man firms. According to the Austrian public census of company units ("Arbeitsstättenzählung"), 329,481 firms are led only by a solo-entrepreneur, representing 52.9 percent of all Austrian firms (Statistik Austria, 2013a). Statistics of the Austrian Chamber of Commerce ("Wirtschaftskammer Österreich" = WKÖ) reveal a lower level of one-person enterprises with 266,910 units, which is due to the fact that a variety of freelancers are not included in the data. ${ }^{1}$ Compared to the total number of firms registered in the Chamber of Commerce, the share of oneperson enterprises thus amounts to 57.3 percent (see Table 1). Since 2008 the number of one-person enterprises in Austria has risen by 30.0 percent. During the last year alone (2013), an increase of 6.3 percent was observed. In the federal state of Carinthia there are 16,446 one-person firms listed in the register of the Chamber of Commerce. Here, the share of one-person entrepreneurs among all enterprises amounts to 55.6 percent. The development over time is very close to the whole of Austria. Hence, since 2008 the number of oneperson enterprises in Carinthia has increased by 30.8 percent. In 2013 the rise was slightly higher than in Austria (9.5 percent).

Table 1. Key Figures for One-person Enterprises in Austria and Carinthia, 2013

\begin{tabular}{|c|c|c|}
\hline Indicator & Austria & Carinthia \\
\hline Number of one-person enterprises & 266,910 & 16,446 \\
\hline Share among all enterprises & $57.3 \%$ & $55.6 \%$ \\
\hline$\Delta$ percent 2008-2013 & $30.0 \%$ & $30.8 \%$ \\
\hline$\Delta$ percent 2012-2013 & $6.3 \%$ & $9.5 \%$ \\
\hline
\end{tabular}

Source: WKÖ (2013a); WKK (2014); own calculations and depiction

Solo-firms have their domains in the business and craft sector, as well as the information and consulting branch, where the share of one-person enterprises among all enterprises is higher than 60 percent. Additionally, with a share of 47.5 percent the trade sector has a high ratio of one-person enterprises (WKK, 2013; WKÖ, 2013b).

${ }^{1}$ In this sense, freelancers have no business licence and are not organized in a legal representation. 
When reasoning about micro-firms operated by solo-self-employed individuals, a critical question is if this remarkably high representation of oneperson enterprises is a new phenomenon, or if it has always existed, without being taken into theoretical and empirical account in the academic sphere. Part of an answer must be that small business owners with shops or in small handicraft production have a very long tradition, but in recent times new technological developments (keyword „digital age“) have opened up new grounds for new firms, many of these being very small. The related structural change in the labour market towards a service sector dominated economy, changing behaviour and life-styles and related new demands and new occupations have contributed to a push towards new forms of self-employment (Gatterer and Kühmayer, 2010; Mandl et al., 2009). Finally, classic jobs in wage- or salary-dependent work (e.g. in the IT and consulting sector, but also in wide fields of health care) are continuously replaced by self-employed activities (Korunka et al., 2011).

Our hypothesis is that one-person enterprises and their owners can be divided into two subgroups: On the one hand, there are one-person entrepreneurs, who are primarily governed by motives of self-reliance and autonomy, flexible working times and a related positive work-family-life balance (Bank Austria, 2012; Mandl et al., 2007). On the other hand, the second subgroup may be primarily pushed into self-employment due to unemployment or precarious labour market situations.

In general, self-employment can also be considered as a driver of poverty. Statistical figures for annual gross incomes of dependent employees and selfemployed people show that the incomes in self-employment are lower and that the indices for median and mean figures differ considerably in selfemployment, which means that volatility and divergencies amongst selfemployed incomes are very strong. Comparing the medians of incomes indicates that self-employment incomes are less than half of the incomes of employees. These figures suggest that many incomes are close to poverty and/or are not sufficient to allow as single subsistence but must be combined with further sources of income.

Moreover, the risk of becoming poor is significantly higher for selfemployed people than for wage- or salary-dependent employees. People who have a household income below the 60 percent line of the median are counted as poverty-vulnerable. The ratio of poverty vulnerability marks the risk of getting poor for specific social and economic status categories. For the dependent working people this ratio is at approximately 17 percent and for selfemployed people it is at 23 percent. In addition, the equivalised incomes of the self-employed people are on average 26 percent below the at-risk-of-poverty threshold; under the employees this poverty gap is only 18 percent (see Table 2 ). The comparison between employees and self-employed people further shows that the self-employed are more highly affected by financial deprivation, which mirrors the inability to participate in the defined minimum standard of living. Accordingly, 26 percent of all self-employed people are financially deprivated compared to 20 percent for the category of employees (Statistik 
Austria, 2013e). Additionally, the durability of the poverty risk is much higher for entrepreneurs than for employees. While 85 percent of the employees were never close to poverty, the ratio for the category of entrepreneurs is significantly lower at 59 percent (Statistik Austria, 2013e).

Table 2. Annual Incomes, Poverty Rate and Poverty Gap by Primary Source of Income, 2012 (in percent)

\begin{tabular}{|c|c|c|c|c|}
\hline $\begin{array}{c}\text { Primary source of } \\
\text { income }\end{array}$ & $\begin{array}{c}\text { Annual gross } \\
\text { income Median }\end{array}$ & $\begin{array}{c}\text { Annual gross } \\
\text { income Mean }\end{array}$ & $\begin{array}{c}\text { Poverty } \\
\text { rate }\end{array}$ & $\begin{array}{c}\text { Poverty } \\
\text { gap }\end{array}$ \\
\hline Employment & $€ 24,843$ & $€ 29,017$ & $17 \%$ & $18 \%$ \\
\hline Self-employment & $€ 11,553$ & $€ 24,077$ & $23 \%$ & $26 \%$ \\
\hline
\end{tabular}

Source: Statistik Austria (2013b); (2013c); Rechnungshof (2012); own depiction

Public statistics for bankruptcies also highlight the partially precarious situations of solo entrepreneurs: In 2012 6,267 company bankruptcies were registered, of which nearly half (55.3 percent) belonged to solo-entrepreneurs and one-person companies (AKV, 2013). Also, Statistik Austria (2013d) shows that one-person firms are overrepresented in relation to bankruptcies. More than three quarters (77.1 percent) of all business company exits in 2011 were one-(wo)man firms, which is significantly higher than their representation within the population of all companies (66.5 percent).

\section{Empirical Results}

\section{Design of the Empirical Survey}

Although self-employed people generate lower incomes on average, are increasingly affected by poverty, financial deprivation, as well as insolvencies and company closures, an upward trend in the field of self-employment can be observed. This development is mainly due to factors like the technological development ("digital age"), the structural change on the labour market towards a service economy, or changing social preferences. Especially oneperson enterprises play an important role in the Austrian business sector. But what are the economic and social rationalities of these micro entrepreneurs; what are their motives for being self-employed? How satisfied are the oneperson enterprises with their professional situation; what about their economic and financial situation and finally, is their emergence due to missing chances in the labour market? In order to answer these questions, a comprehensive online survey has been implemented in cooperation with the Chamber of Commerce in Carinthia. The survey is based on a questionnaire containing 52 questions in total. This questionnaire has been developed and tested in a process lasting several months and has finally been adapted for the online survey with the help of appropriate software (LimeSurvey). The contents of the questionnaire refer to the extent and motives of self-employment, client relations, success and satisfaction with self-employment, future prospects of the one-person enterprises, and socio-economic characteristics. 
In February 2014, a total of 9,002 one-person enterprises were contacted by the Carinthian Chamber of Commerce and invited to participate in the online survey. The response rate was 7.0 percent, resulting in a sample size of 626 one-person enterprises. The generated sample is representative with respect to the legal form (over 90 percent individual entrepreneurs), age (mean age in the sample and in the total population: 47 years) and gender, with males being slightly overrepresented in the sample compared to the total population. Regarding the economic sector, Table 3 shows that one-person enterprises from the information and consulting branch are considerably overrepresented (sample: 30.2 percent, basic population: 15.8 percent). This result may be due to the higher affinity for technology of this group of entrepreneurs and the associated familiarity with online surveys. Conversely, business and craft enterprises are represented less in the sample ( 37.4 percent) than in the total population (48.5 percent). Moreover, gender-related differences can be observed. While business and craft enterprises are mainly female (share of women: 51.1 percent), the information and consulting sector is dominated by men (share of men: 73.5 percent).

Table 3. Sector of the One-person Enterprises in the Sample Compared to the Basic Population

\begin{tabular}{|c|c|c|c|}
\cline { 3 - 4 } \multicolumn{2}{c|}{} & \multicolumn{2}{c|}{ Basic population } \\
\hline Economic sector & Sample $(n=626)$ & absolute & in percent \\
\hline Business and craft & $37.4 \%$ & 7,654 & $48.5 \%$ \\
\hline Industry & $1.8 \%$ & 190 & $1.2 \%$ \\
\hline Trade & $17.7 \%$ & 3,640 & $23.1 \%$ \\
\hline Transport & $1.6 \%$ & 407 & $2.6 \%$ \\
\hline Tourism and leisure & $8.1 \%$ & 1,389 & $8.8 \%$ \\
\hline Information and consulting & $30.2 \%$ & 2,494 & $15.8 \%$ \\
\hline Banking and insurance & $0.0 \%$ & 1 & $0.0 \%$ \\
\hline Other & $2.2 \%$ & 0 & $0.0 \%$ \\
\hline Don't know & $1.0 \%$ & 0 & $0.0 \%$ \\
\hline In total & $\mathbf{1 0 0 . 0} \%$ & $\mathbf{1 5 , 7 7 5}$ & $\mathbf{1 0 0 . 0 \%}$ \\
\hline
\end{tabular}

Source: Wirtschaftskammer Kärnten (2014); own calculations

Additionally, the information and consulting sector exhibits a high share of academics (46.6 percent), while one-person enterprises in the remaining economic fields are significantly less educated. Hence, in these economic sectors, the share of one-person enterprises with a school education below high school level (Matura) is greater than 50 percent.

Identification of Precarious Forms of One-person Enterprises based on the Collected Data

As indicated above, the empirical survey covers a wide range of issues related to self-employment as a one-person enterprise. The empirical results of this paper focus on the motives for being self-employed and the associated identification of precarious forms of one-person enterprises. 
The main motives for self-employment are shown in Figure 1. The mostoften cited argument for being self-employed (62.1 percent of the respondents) is the possibility of self-determined working and the associated higher level of responsibility. In addition, 42.5 percent

of the respondents think that self-employment represents the best way to develop their own creativity and achieve personal fulfilment. Finally, more flexible working hours and the associated improved work-life-balance rank among the major rationalities for setting up a business. Regarding the motives for being self-employed, we also observed gender-related differences. Both, the improved reconciliation of work and family life, as well as the more flexible working time play a greater role for women than for men, while higher income opportunities are a major incentive for male entrepreneurs.

Figure 1. Motives for Self-employment (multiple answers; in percent)

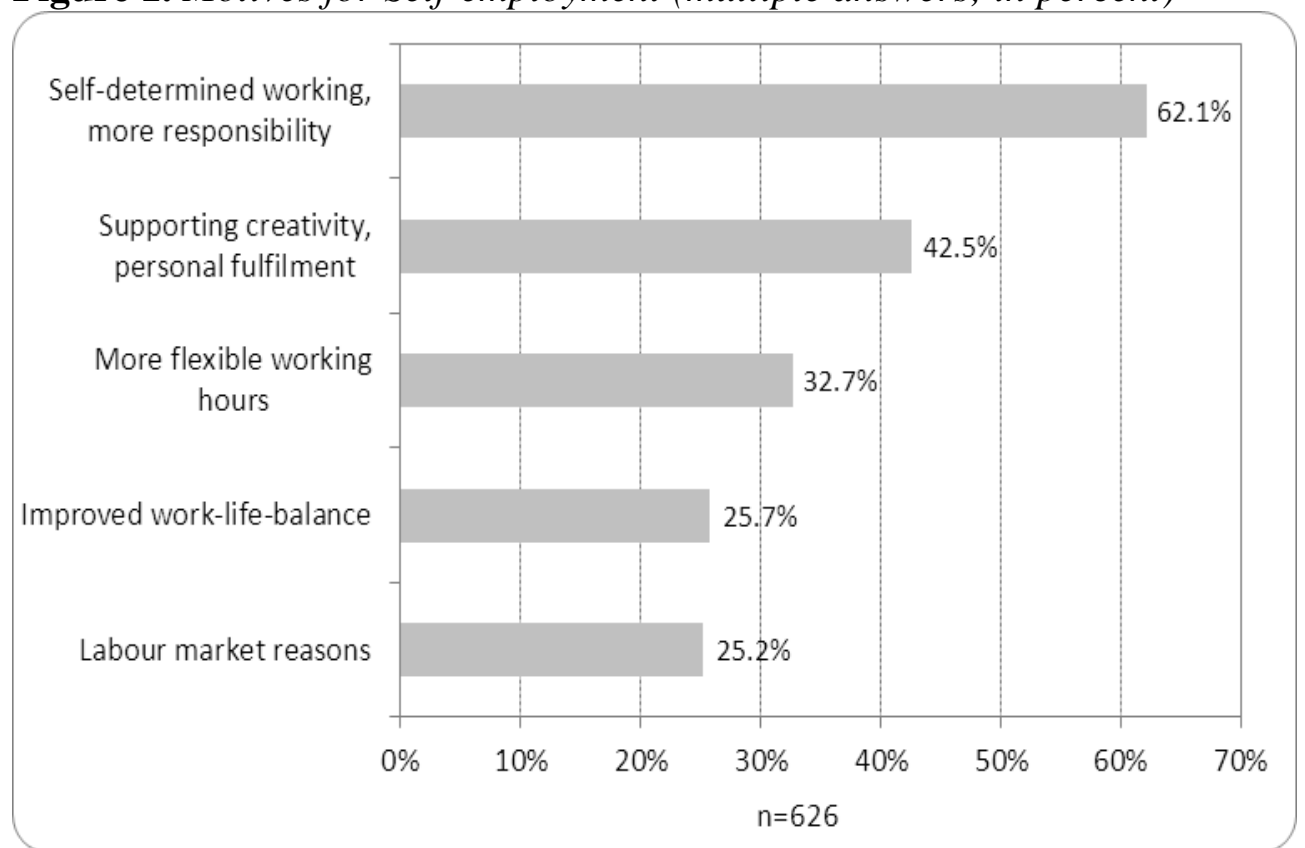

Source: Own calculations and depiction

Beside these non-economic factors, economic motives play an increasingly important role for the decision to become self-employed. Hence, about one quarter ( 25.2 percent) of the one-person enterprises decided to work as an entrepreneur due to labour market reasons. ${ }^{1}$ Labour market reasons refer to

- the individual inability to find dependent employment,

- the precarious labour market situation that requires selfemployment, or

\footnotetext{
${ }^{1}$ Additionally, 16.9 percent of the respondents stated that they started their business activities as a one-person enterprise during or subsequent to a period of unemployment. These results are also in line with the young business survey from Statistik Austria (2007, $83 \mathrm{ff}$ ). In this survey, preventing unemployment represents one of the main motives for the formation of an own company.
} 
- the representation of self-employment as an alternative to or escape from unemployment.

Based on the collected data, the main objective of this article is to identify these precarious forms of one-person enterprises (self-employment due to the above mentioned labour market reasons) and analyse whether this group of solo-entrepreneurs differs from the one-person enterprises that started their business activities based on non-economic factors with regard to age, job satisfaction, the economic situation or future prospects. For this purpose, the whole sample was divided into two subsamples:

- Subsample (1): One-person enterprises for which we found evidence that they are crowded out from the dependent labour market $(n=158)$.

- Subsample (2): One-person enterprises that are driven by non-economic factors $(n=468)$.

Subsequently, we analysed whether the frequency distribution of certain characteristics differs between the two groups. The results of this comparative analysis are shown in

Table 4.

First of all, we found out that in the subgroup of precarious microentrepreneurs (self-employed due to labour market reasons) the share of individuals aged older than 45 years is significantly higher (69.0 percent) as compared to the reference group which become self-employed based on other, non-economic factors (53.6 percent). Consequently, labour market reasons as a motive for self-employment are predominantly given in the age group greater than 45 years, rather than in the younger reference group. Hence, about 30.3 percent of the one-person entrepreneurs older than 45 years decided to become self-employed due to labour market factors, whereas this is only true for 18.4 percent of the younger counterparts up to an age of 45 years (statistical significance of the correlation: Pearson- $\chi^{2}=11.397$, $p$-value $=0.001$ ). This result may relate to the fact that elderly people ( $>50$ years) principally face problems in the labour market. According to that, older employees are intensively affected by unemployment and are more often unemployed for a longer period (long-term unemployment). ${ }^{1}$ Self-employment may represent a way out of their precarious labour market situation.

Regarding job satisfaction, we also found significant differences based on the motives for becoming self-employed. In the subsample of the precarious one-person enterprises (labour market reasons), the share of respondents that is dissatisfied with the professional situation is more than twice as high as in the reference group (see

\footnotetext{
${ }^{1}$ In the age group greater than 50 years the unemployment rate in Austria amounts to 8.2 percent; by contrast, the total Austrian unemployment rate is 7.6 percent and thus below this value (AMS-Database, 2014).
} 
Table 4). This difference was also found to be statistically significant at the 1 percent level (Pearson- $\chi^{2}=16.741$, p-value $=0.000$ ).

Moreover, the economic situation of individuals in one-person businesses who decided to work as entrepreneurs due to labour market reasons is comparatively poor. As can be seen from

Table 4, nearly three quarters (74.7 percent) of the "precarious" forms of one-person enterprises generate a monthly net income of up to $€ 1,500$. In the reference group this share amounts to merely 65.4 percent. Hence, one-person enterprises driven by non-economic factors perfom comparatively better, and thus, generate higher incomes (Pearson- $\chi^{2}=4.673$, $p$-value $=0.031$ ).

Table 4. Results of the Comparative Statistical Analysis

\begin{tabular}{|c|c|c|c|c|c|}
\hline Variable & $\begin{array}{c}\text { Attribute } \\
\text { levels }\end{array}$ & $\begin{array}{l}\text { Subgroup: } \\
\text { labour } \\
\text { market } \\
\text { reasons } \\
(n=158)\end{array}$ & $\begin{array}{c}\text { Subgroup: } \\
\text { other } \\
\text { motives } \\
(n=468)\end{array}$ & $\begin{array}{c}\text { Statistical } \\
\text { relationship: } \\
\text { Cramers V }\end{array}$ & $\begin{array}{c}\text { Pearson- } \chi^{2} \\
(p \text {-value })\end{array}$ \\
\hline Age & $\begin{array}{l}\leq 45 \text { years } \\
>45 \text { years }\end{array}$ & $\begin{array}{l}31.0 \% \\
69.0 \% \\
\end{array}$ & $\begin{array}{l}46.4 \% \\
53.6 \% \\
\end{array}$ & 0.135 & $\begin{array}{c}11.397 * * * \\
(0.001)\end{array}$ \\
\hline $\begin{array}{c}\text { Job } \\
\text { satisfaction }\end{array}$ & $\begin{array}{l}\text { Very/rather } \\
\text { satisfied } \\
\text { Rather/very } \\
\text { unsatisfied }\end{array}$ & $\begin{array}{l}71.5 \% \\
28.5 \%\end{array}$ & $\begin{array}{l}85.9 \% \\
14.1 \%\end{array}$ & 0.164 & $\begin{array}{c}16.741 * * * \\
(0.000)\end{array}$ \\
\hline $\begin{array}{l}\text { Monthly net } \\
\text { income }\end{array}$ & $\begin{array}{l}\leq 1,500 € \\
>1,500 €\end{array}$ & $\begin{array}{l}74.7 \% \\
25.3 \% \\
\end{array}$ & $\begin{array}{l}65.4 \% \\
34.6 \% \\
\end{array}$ & 0.086 & $\begin{array}{c}4.673 * * \\
(0,031) \\
\end{array}$ \\
\hline $\begin{array}{l}\text { Future } \\
\text { prospects }\end{array}$ & $\begin{array}{l}\text { Very/rather } \\
\text { optimistic } \\
\text { Rather/very } \\
\text { pessimistic }\end{array}$ & $\begin{array}{l}77.8 \% \\
22.2 \%\end{array}$ & $\begin{array}{l}88.9 \% \\
11.1 \%\end{array}$ & 0.139 & $\begin{array}{c}12.033 * * * \\
(0.001)\end{array}$ \\
\hline \multicolumn{3}{|c|}{ Significance: $* * * 1$ percent level } & ercent & $* 10$ & ent level \\
\hline
\end{tabular}

Source: Own calculations

Finally, one-person entrepreneurs that decided to be self-employed due to labour market reasons are less optimistic regarding their entrepreneurial future. In total, 22.2 percent assess the future perspective of their business as rather or very pessimistic, a share that is twice as high as in the reference group of the non-precarious one-person enterprises (see

Table 4). Moreover, the correlation between future prospects and motives for self-employment is highly statistically significant (Pearson- $\chi^{2}=12.033, \mathrm{p}$ value $=0.001$ ). 


\section{Concluding Remarks}

Data from official statistics show a clear growth trend in the field of selfemployment resulting from factors like the structural change on the labour market towards a service economy, or changing social preferences and living conditions. Closely related to this, is an emerging trend towards one-person enterprises, which already represent more than 50 percent of all Austrian companies. Although the working life of an individual entrepreneur or oneperson enterprise is associated with advantages like more self-responsibility, working without hierarchies and more flexible working hours, the business activity is subject to major disadvantages. Many one-person enterprises are struggling to survive economically. Evidence can be found in the data from official statistics, which indicate that self-employed people earn - based on yearly median incomes - significantly less as compared to employed wage earners. Moreover, self-employed persons are more often affected by poverty, financial deprivation and insolvencies.

In fact, about one quarter (25.2 percent) of the respondents from our survey choose the way into self-employment for one or more economic or labour-market relevant reasons. Hence, these people are working as a oneperson enterprise because they were unable to find dependent employment, wanted to escape from unemployment, or found themselves in an economic situation that required self-employment. On the basis of statistical comparison analyses we found evidence that these one-person enterprises are more frequently dissatisfied with their professional situation, are less optimistic regarding their entrepreneurial future, earn less and mainly belong to the older age group ( $>45$ years). However, this does not mean that individuals in oneperson enterprises that started their business from a precarious labour market situation are unable to perform successfully as an entrepreneur. On the contrary, precarious labour market conditions may also open opportunities for the persons affected. In any case, one-person enterprises represent a very heterogeneous group in the field of self-employment. This can be shown on the basis of the collected data. Beside the established and economically successful one-person enterprises, one-person enterprises may also represent sideline businesses in the sense of a combination between independent and dependent employment (hybrid forms of entrepreneurs). Finally, there also exist necessity-driven one-person enterprises that were crowded out from the (dependent) labour market. Due to this heterogeneity, it is extremely important to differentiate: One-person enterprises may be driven by different motives and may exhibit diverging social constellations and professional biographies. In this respect, empirical research is required in order not to remain in the realm of speculation.

Beside the limitations of the paper regarding its focus on Carinthia, we see some very general evidence that in contrast to stereotypical assumptions, the phenomenon of entrepreneurship may look totally different when it is studied as a phenomenon embedded in the labour markets and specific occupational contexts, applications and sectors (see e.g. Welter and Lasch, 2008). Some 
types of small businessmen and independent professionals belong to a category, which does not fit with the "clean" image of entrepreneurship. They do not show ambition for growth and they are sometimes very close to low income ranges, occasionally to poverty (Kautonen et al., 2010; Shane, 2008). Empirical studies on diverse groups of self-employed individuals in larger societal and labour market contexts produce alternative pictures, challenging stereotypical assumptions and rhetoric related to entrepreneurship (see Blackburn and Kovalainen, 2008).

Especially being in an entrepreneurial society (Audretsch, 2007) must be furnished sociologically. One has to upgrade it with the challenge of an appropriate definition of entrepreneurship at least. Baumol (1990), Zahra (2006) and Welter (2011) have brought to attention that researchers are faced by a multiplicity of contexts and that one has to distinguish between those institutional variables. Aiming to understand the formation of markets and the inherent competition processes (Freeman et al. 1983) one needs both empirical studies but also a theoretical framework of socioeconomics helping to investigate entrepreneurship formation seriously in a wider concept.

\section{References}

AKV - Alpenländischer Kreditorenverband (2013): Insolvenzstatistik, vollständige Übersicht aller Insolvenzfälle in Österreich, Gesamtjahr 2012. Vienna.

Acemoglu, D. (2001). Good Jobs versus Bad Jobs. In: Journal of Labor Economics, Vol. 19 (1), 1-21.

Amorós, J. E. and Bosma, N. (2014): Global Entrepreneurship Monitor, 2013 Global Report. Fifteen Years of Assessing Entrepreneurship Across the Globe. Santiago de Chile.

AMS-Database (2014): Arbeitslosigkeit, Beschäftigung und Arbeitslosenquoten nach Bundesländern (Datum: 2013). http://iambweb.ams.or.at/ambweb/ (Download 23.05.2014).

Audretsch, D.B. (2007): The Entrepreneurial Society. Oxford University Press: Oxford.

Bank Austria (2012): Ein-Personen-Unternehmen. Charakteristika, Rahmenbedingungen und der Weg zum Erfolg. UniCredit Bank Austria AG: Vienna.

Baumol, W.J. (1990). Entrepreneurship: Productive, Unproductive, and Destructive. In: Journal of Political Economy, Vol. 98 (5), 893-921.

Blackburn, R. and Kovalainen, A. (2008): Researching small firms and entrepreneurship: Past, present and future. In: International Journal of Management Review 11, No. 2, 127-148.

Bögenhold, D. (2013): Social Network Analysis and the Sociology of Economics: Filling a Blind Spot with the Idea of Social Embeddedness. In: The American Journal of Economics and Sociology, Vol. 72, No. 2, 293-318.

Bögenhold, D., Fachinger, U. and Leicht, R. (2001): Entrepreneurship, SelfEmployment, and Wealth Creation. In: The International Journal of Entrepreneurship and Innovation No. 2, 81f.

Bögenhold, D. and Fachinger, U. (2007): Micro-firms and the Margins of Entrepreneurship: The Restructuring of the Labour Market. In: The International Journal of Entrepreneurship and Innovation, No. 8, 281f. 
Bögenhold, D., Fink, M. and Kraus, S. (2014a): Integrative Entrepreneurship Research - Bridging the Gap between Sociological and Economic Perspectives. In: International Journal of Entrepreneurial Venturing, Vol. 6, 118-139.

Bögenhold, D., Heinonen, J. and Akola, E. (2014b): Entrepreneurship and Independent Professionals. Social and Economic Logics. In: International Advances in Economic Research, Vol. 20, 295-310.

Bonnet, J., Dejardin, M., and Madrid-Guijarro, A. (Eds.) (2012): The Shift to the Entrepreneurial Society: A Built Economy in Education, Support and Regulation. Edward Elgar: Cheltenham.

Bonnet, J.,García-Pérez-de-Lema, D. and van Auken, H. (Eds.) (2010): The Entrepreneurial Society: How to fill the Gap between Knowledge and Innovation. Edward Elgar: Cheltenham.

Burke, A.E., Fitz Roy, F.R. and Nolan, M.A. (2005): What makes a Die-Hard Entrepreneur? Trying, or Persisting in Self-employment, Max-Plank Foundation, Discussion Papers on Entrepreneurship, Growth, and Public Policy, Jena.

Burt, R. S., Kilduff, M. and Tasselli, S. (2013): Social Network Analysis: Foundations and Frontiers on Advantage. In: Annual Review of Psychology, Vol. 64, 527-547.

Davidsson, P. (2014): The Field of Entrepreneurship Research: Some Significant Developments. Unpublished research Paper.

Davidsson, P. and Honig, B. (2003): The role of social and human capital among nascent entrepreneurs. In: Journal of Bus-iness Venturing, 18 (3), 301-331.

Davidsson, P., Achtenhagen, L., and Naldi, L. (2010): Small firm growth. In: Foundations and Trends in Entrepreneurship, 6(2), 69-166.

Eurostat-Database (2014): Selbstständigkeit nach Geschlecht, Alter und Beruf (lfsa_esgais). http://epp.eurostat.ec.europa.eu/portal/page/portal/statistics/search_ database (Download 11.05.2014).

Folta, T., Delmar, F. and Wennberg. K. (2010): Hybrid Entrepreneurship. In: Management Science, 56, $253 \mathrm{f}$.

Freeman, J., Carroll, G.R. and Hannan, M.T. (1983): The Liability of Newness: Age Dependence in Organizational Death Rates. In: American Sociological Review, $48,5,692 \mathrm{f}$.

Gatterer, H. and Kühmayer, F. (2010): EPU machen Zukunft. Trenddossier zur Zukunft von Ein-Personen-Unternehmen. Zukunftsinstitut Österreich GmbH: Vienna.

Kalleberg, A. L. (2009): Precarious Work - Insecure Workers. Employment Relations in Transition. In: American Sociological Review 74 (1), 1-22.

Kalleberg, A. L. (2011): Good Jobs, Bad Jobs. The Rise of Polarized and Precarious Employment Systems in the United States. Russel Sage Foundation: New York.

Kautonen, T., Down, S., Welter, F., Vainio, P. and Palmroos, J. (2010): Involuntary self-employment as a public policy issue: a cross-country European view. In: International Journal of Entrepreneurial Behaviour and Research 16, No. 1-2, $112-129$.

Korunka, G., Kessler, A., Frank, H. and Lueger, M. (2011): Conditions for growth in one-person-startups: A longitudinal study spanning eight years. In: Psicothema, Vol. 23, 446-459.

Leicht, R. (2000): Die 'neuen Selbständigen' arbeiten alleine. Wachstum und Struktur der Soloselbständigen in Deutschland. In: Internationales Gewerbearchiv 48, $75 \mathrm{f}$.

Mandl, I., Dörflinger, C., Gavac, K., Hölzl, K., Kremser, S. and Pecher, I. (2007): EinPersonen-Unternehmen in Österreich, Endbericht. KMU Forschung Austria: Vienna. 
Mandl, I., Gavac, K. and Hölzl, K. (2009): Ein-Personen-Unternehmen in Österreich. In: Wirtschaft und Gesellschaft 35, $215 \mathrm{ff}$.

OECD and The European Commission (2013): The Missing Entrepreneurs. Policies for Inclusive Entrepreneurship in Europe. OECD: Paris.

Rechnungshof (2012): Bericht des Rechnungshofes über die durchschnittlichen Einkommen der gesamten Bevölkerung (Allgemeiner Einkommensbericht 2012). Vienna.

Schumpeter, J.A. (1912): Theorie der wirtschaftlichen Entwicklung. J.C.B. Mohr: Tübingen.

Shane, S. (2008): The Illusions of Entrepreneurship. Yale University Press: New Haven.

Shane, S. and V. Venkataraman (2000): The Promise of Entrepreneurship as a Field of Research. In: Academy of Management Review, Vol. 25, No. 1, 217-260.

Statistik Austria (2007): Erfolgsfaktoren österreichischer Jungunternehmen. Vienna.

Statistik Austria (2013a): Census 2011 Arbeitsstättenzählung, Ergebnisse zu Arbeitsstätten aus der Registerzählung. Vienna.

Statistik Austria (2013b): Statistisches Jahrbuch 2014. Vienna.

Statistik Austria (2013c): Tabellenband EU-SILC 2012, Einkommen, Armut und Lebensbedingungen. Vienna.

Statistik Austria (2013d): Ergebnisse im Überblick: Statistik zur Unternehmensdemografie 2004 bis 2011, Untergliederung nach Rechtsform. Vienna.

Statistik Austria (2014): STATCube Datenbank: Mikrozensus Arbeitskräfteerhebung Jahresdaten. Vienna.

Stigler, G. T. (1949): A Survey of Contemporary Economics. In: Journal of Political Economy, Vol. 57 (2), 93-105.

Tilly, C. (1996). Half a Job. Bad and Good Part-time Jobs in a Changing Labor Market, Philadelphia: Temple University Press.

Welter, F. (2011): Contextualizing Entrepreneurship - Conceptual Challenges and Ways Forward. In: Entrepreneurship Theory and Practise, Vol. 35, 165-184.

Welter, F. and Lasch, F. (2008): Entrepreneurship Research in Europe: Taking Stock and Looking Forward. In: Entrepreneurship Theory and Practice, Vol. 32, 241248.

Wiklund, J., Davidsson, P., Audretsch, D.B. and Karlsson, C. (2011): The Future of Entrepreneurship Research. In: Entrepreneurship Theory and Practice 35, No. 1, $1-9$.

WKK - Wirtschaftskammer Kärnten (2013): Fachgruppenkatalog, Klagenfurt.

WKK - Wirtschaftskammer Kärnten (2014): EPU-Statistik, Sonderauswertung. Klagenfurt.

WKÖ - Wirtschaftskammer Österreich (2013a): Ein-Personen-Unternehmen (EPU) 2013, EPU-Anteil nach Bundesländern (EinzelunternehmerInnen, GmbH). Vienna.

WKÖ - Wirtschaftskammer Österreich (2013b): Ein-Personen-Unternehmen (EPU) 2013, EPU-Anteil nach Sparten (Mehrfachmitgliedschaften) (EinzelunternehmerInnen, GmbH). Vienna.

Zahra, S.A. (2006): Contextualizing theory building in entrepreneurship research. In: Journal of Business Venturing, 22 (3), 443-452. 
